\title{
A Study on Reflective Learning Model Implementation to Improve Prospective Biology Teachers' Creativity
}

\author{
Efriana Jon $^{1 *}$, Asni Johari ${ }^{2}$, M. Haris Effendi Hsb ${ }^{3}$, Bambang Hariyadi ${ }^{4}$ \\ ${ }^{1}$ MIPA Education Doctoral Program, Jambi University, Indonesia \\ ${ }^{2,3,4} \mathrm{Jambi}$ University, Indonesia \\ *Corresponding Author: Efriana Jon, efrianajon86@gmail.com
}

\begin{abstract}
Previous studies have shown that the creativity of students who are prospective biology teacher is still low. Even though some efforts have been made, the level of creativity is still low and needs to be improved. This is important before the students become teachers in the community. This study thus aims to examine the effectiveness of the reflective learning model in improving the creativity of students who are prospective biology teachers. This is a literature review study that collect references from various sources, such as journals on Google Scholar, Science Direct, Mendeley and many more to answer the research question. The results showed that the reflective learning model can improve creativity; thus, it is recommended to be applied by lecturers in teaching students who are prospective biology teachers.
\end{abstract}

Keywords: learning model, reflective learning, creativity ability, prospective biology teachers.

\section{Introduction}

Students are excellent human resources. However, not all students can think creatively when facing problems in real life. Creative thinking is essential in various aspects of life. It will help students later when they face a competition in the future (Warren, et al, 2020). According to Makmur (2015), creativity is a process that demands a balance and application of three essential aspects, namely analytical, creative and practical intelligence. It has four important dimensions for self-expression, namely: 1) fluency, which is the ability to generate a large number of ideas or problem solutions, 2) flexibility, which refers to the ability to generate ideas, 3) originality, which is the ability to generate new and original ideas, and lastly 4) elaboration, which is the ability to think in detail and systematically (Munandar, 2006).

Munandar (2004) states that creativity is characterized by sense of curiosity, imagination, feeling challenged, courage to take risks, and appreciation. Students with these characteristics will typically be quality graduates who are able to survive and make an innovation in the future (Bridgstock et al., 2015). Lack of creativity, on the other hand, can impact their readiness to become future teachers. To develop creativity, students need to have motivation and self-awareness. Motivation will keep them enthusiastic and willing to learn independently, while self-awareness will encourage them to explore and find new things during the learning process. They will also develop the ability to reason, think critically and creatively.

There have been various attempts made in the world of education to develop students' creativity. One of which is through the independent learning curriculum. However, in reality, the results have not yet met the expectation. Especially during the pandemic, the learning 
processes have undergone some limitation, with teachers having constraints in guiding students. Furthermore, the teaching and learning processes are still teacher-centered, thus making the students passive. In the class, the students mainly listen, take notes, memorize and do the tasks assigned by teachers (Handoko, 2017). They are mostly dictated to follow certain instructions, which inhibits their ability to think creatively.

Abadzi et al. (2019) states that todays' era has demanded a generation of creative thinkers. Yet, ironically, many students these days are unable to identify, guess, and find a solution (Oktora et al., 2018). In a study by Sri (2012), students were found to only be able to pass final exams. They were oriented only to being able to do well on tests, not to being able to solve problems creatively. Dewi et al. (2018) thus encourage that teachers develop students' creative thinking through open questions or problem-based activities.

Using the right learning model can also help to develop students' creativity. According to Budiarti (2015), a learning model is a tool to improve creativity. One learning model developed for this purpose is the reflective learning model. It helps develop students' thinking processes through self-reflection because the ability to reflect to oneself is the basis of human thinking and creativity. Having a high level of creativity is critical for prospective teacher students, especially prospective biology education teachers because they are required to teach after graduation.

Reflective learning model involves reflective thinking activities in the learning process, with an aim to encourage students' activeness and maximize their potential. Reflection is an intellectual activity and affective aspect that invite students to recall their experiences to achieve understanding and generate new ideas to solve a certain problem (Rohana \& Ningsih, 2016).

\section{Method}

This is a literature review study that discusses theories, findings, and other relevant materials from various sources (Syafnidawati, 2020). Snyder (2019) said that literature review is a research methodology that aims to collect, extract the essence of previous research, and analyze several overviews of experts written in the text. This research used a narrative review approach, or also known as a semi-systematic approach, that is designed for themes that have been conceptualized and studied by different researchers from different disciplines to find out and describe clearly a certain phenomenon (Wong et al., 2013 in Snyder, 2019). The sources are Google Scholar, Science Direct, Mendeley and other supporting references. The keywords are a learning model, reflective learning, and creativity. The scope of references is limited to the reflective learning model to increase the creativity of students who are prospective biology teachers.

\section{Results and Discussion}

A study carried out by Omar et al. (2017) on Saudi female students at the King Saud University showed that the reflective learning model helped building the students' critical thinking and curiosity for new knowledge and insights. It also developed high-level skills and helped students to connect new knowledge with the previously gained knowledge. Not only does the reflective learning benefit the students, it is also useful to improve teachers' skills and performance (Leila, 2016). 
Reflective learning can help students become more qualified and professional in carrying out their tasks as prospective teachers. It also improves students' reflectivity and provides more insights as a result of creative learning experiences (Ingridwati, 2011). Hojeij et al. (2021) reported that the reflective learning model is effective in guiding students to write a reflective journal, helping teachers examine and improve the teaching process, and improving students' learning experiences (Hojeij, et al. 2021). Another study by Jordi et al. (2012) found that the reflective learning model can generate self-knowledge of students, in which they are able to connect their experiences with new knowledge and reflect on themselves after the learning process ends. Furthermore, they can regulate themselves during the learning process and develop creativity.

\section{Conclusion}

From the previous research, it can be concluded that the reflective learning model can improve students' creativity. Hence, this learning model is highly appropriate to use to improve the creativity of students who are prospective biology teachers. Using this model is advantageous, especially during this pandemic, because it allows students to do self-reflection after the learning process. Self-reflection, as mentioned earlier, is the basis of human thinking and creativity. In addition, teachers' skills and performance can be improved through this model application.

\section{References}

Abadzi, A., M. Martelli \& S. Primativo. (2009). Explorations of Creativity: A Review for Educators and Policy Making. Qatar: WISE Qatar Foundation.

Bridgstock, R., Goldsmith, B., Rodgers, J., \& Hearn, G. (2015). Creative graduate pathways within and beyond the creative industries. Journal of Education and Work, 28(4), 333345.

Budiarti, Y. (2015). Pengembangan Kemampuan Kreativitas dalam Pembelajaran IPS. Jurnal Promosi, 61-72.

Colomer, J., Pallisera, M., Fullana, J., Burriel, M.P, Fernández, R. (2012). Reflective Learning in Higher Education: A Comparative Analysis. Procedia - Social and Behavioral Sciences, ISSN: 364-370. https://doi.org/10.1016/j.sbspro.2013.09.204

Dewi, N. R., \& Masrukan, M. (2018). Peningkatan Kemampuan Berpikir Kreatif Mahasiswa Program Magister. PRISMA, Prosiding Seminar Nasional Matematika, 1, 539-546. Retrieved from https://journal.unnes.ac.id/sju/index.php/prisma/article/view/20139

Handoko, H. (2017). Pembentukan Keterampilan Berpikir Kreatif pada Pembelajaran Matematika Model SAVI Berbasis Discovery Strategy Materi Dimensi Tiga Kelas X. EduMa, 6(1). ISSN: 2086-3918.

Hojeij, Z., Meda, L., Kaviani, A. (2021). Using Reflektive Journals for Analysing PreService, Early Childhood Teachers' Perception of Practicum Experiences. Issues in Educational Research, 31(1). Retrieved from https://www.iier.org.au/iier31/hojeij.pdf 
Ingridwati, K. (2011). Pengembangan Model Pembelajaran untuk Meningkatkan Kemampuan Reflektif Mahasiswa S1-PGSD pada Mata Kuliah Penelitian Tindakan Kelas. Prosiding.

Makmur, A. (2015). Efektifitas Penggunaan Metode Base Method dalam Meningkatkan Kreativitas dan Motivasi Belajar Matematika Siswa SMP N 10 Padangsidimpuan. Jurnal EduTech, 1(1).

Munandar, U. (2004). Pengembangan Kreativitas Anak Berbakat. Jakarta: Rineka Cipta.

Munandar, U. (2006). Mengembangkan Bakat dan Kreatifitas Anak Sekolah. Jakarta: PT. Gramedia Widiasarana.

Oktora, S.R., Sudarto, E., \& Mashuri, M. (2018). Penerapan Discovery Learning untuk Meningkatkan Penalaran Induktif Deduktif dan Kreativitas Siswa Kelas X SMA N 3 Semarang. PRISMA. Prosiding Seminar Nasional Matematika, 1, 641-646. Retrieved from https://journal.unnes.ac.id/sju/index.php/prisma/online

Omar, S. (2017). Level of Reflective Practice amongst Saudi Female Postgraduate Students at KSU. English Language and Literature Studies, 7(3), 28. DOI: 10.5539/ells.v7n3p28.

Rohana, R., \& Ningsih, Y. (2016). Model Pembelajaran Reflektif untuk Meningkatkan Kemampuan Pemecahan Masalah Matematis Mahasiswa Calon Guru. Jurnal Penelitian dan Pembelajaran Matematika, 145-158. DOI: http://dx.doi.org/10.30870/jppm.v9i2.992

Snyder, H. (2019). Literature Review as a Research Methodology: An overview and guidelines. Journal of Business Research, 104, 333-339. ISSN: 0148-2963. https://doi.org/10.1016/j.jbusres.2019.07.039

Syafnidawati, S. (2020). Pengertian Literature Review. Universitas Raharja. Retrieved from https://raharja.ac.id/2020/10/13/literature-review/

Tajik, L. (2016). Merancang Kursus Pendidikan Guru Reflektif dan Kontribusinya untuk Reflektifitas Guru ELT. Journal Teaching Education: Australia.

Warren, T., Hardy, J. H., Hardy, C. R., Ebersole, K.L., Viganola, D., Clemente, E.G., Gordon, M., Dreber, A., Johannesson, M., Pfeiffer, T., Uhlmann, E.L. (2020). Organizational Behavior and Human Decision Processes. Elsevier, 168. ISSN: 0749-597. Retrieved from www.elsevier.com/colate/obhdp 